\title{
ANÁLISE DOS PROCESSOS DE SALINIZAÇÃO DAS ÁGUAS SUBTERRÂNEAS DA BACIA DO RIO SALITRE POR MEIO DE TRAÇADORES AMBIENTAIS
}

\author{
Christian Pereira Lopes dos Santos \\ Orientador: Dr. Antonio Expedito Gomes de Azevedo (UFBA) \\ 125 p. - Tese (Doutorado) - Defesa 27.03.2008
}

\begin{abstract}
RESUMO. Os processos de salinização das águas da bacia do rio Salitre foram analisados por meio de dados isotópicos e químicos de amostras de águas subterrâneas e superficiais no intuito de avaliar a participação dos fatores climáticos e geológicos na salinidade dessas águas. Os principais aqüíferos da bacia do rio Salitre são constituídos pelas rochas metassedimentares do Grupo Chapada Diamantina e pelas rochas carbonáticas do Grupo Una e da Formação Caatinga. Dados químicos mostram uma clara distinção entre os dois aqüíferos, um baixo teor de sais dissolvidos nas águas do aqǘfero metassedimentar e um alto teor de sais dissolvidos nas águas do aqüífero cárstico. As composições isotópicas do hidrogênio $(\delta \mathrm{D})$ e do oxigênio $\left(\delta^{18} 0\right)$ das águas subterrâneas e superficiais da bacia variaram numa faixa de $33 \%$ e $4 \%$ (VSMOW) respectivamente. Para as águas do aqǘfero cárstico, valores de $\delta$ D entre $-43 \%$ e $-10 \%$, e do $\delta^{18} 0$ entre $-5,9 \%$ e $-3,3 \%$, com elevado teor de sais dissolvidos, possibilitaram identificar a participação relativa de três mecanismos de salinização. As amostras com valores mais negativos indicam a dominância dos mecanismos de transpiração e/ou dissolução de rochas do tipo evaporíticas, enquanto que amostras com valores menos negativos indicam a dominância de mecanismos de evaporação. Já as amostras do aqǘfero metassedimentar, valores do $\delta$ D entre $-36 \%$ e $-20 \%$, e do $\delta^{18} 0$ entre $-5,4 \%$ e $-3,5 \%$ o sugerem águas pouco evaporadas, com baixo teor de sais dissolvidos, com exceção de uma amostra anômala a qual apresenta alto teor de sais dissolvidos. Em geral, as amostras de águas das barragens de Ourolândia, Tamburil e Caatinga do Moura mostram um grande enriquecimento em isótopos pesados do hidrogênio e oxigênio devido a perdas por evaporação. Nas proximidades dessas barragens, poços amostrados revelam valores isotópicos distintos, os quais comprovam que não há conexão dos poços com esses reservatórios. A composição isotópica do carbono no carbono inorgânico dissolvido $\left(\delta^{13} C_{C I D}\right)$ das águas subterrâneas da bacia variaram entre -16,5\% e -1,7\% (PDB), com amostras do aqǘfero cárstico mais enriquecidas em carbonatos dissolvidos devido à interação água-rocha. Valores do $\delta^{13} \mathrm{C}_{\mathrm{CID}}$ de grupos de amostras do aqǘfero cárstico e metassedimentar possibilitaram identificar a participação relativa de dois mecanismos de salinização na bacia: intemperismo da rocha por ácido carbônico e intemperismo da rocha por ácido sulfúrico. 0 grupo de amostras do aqǘfero cárstico com valores de $\delta^{13} C_{C I D}$ entre $-16,5 \%$ e $-8,0 \%$ indicam zonas de dominância do intemperismo de carbonatos por ácido carbônico, enquanto que o grupo de amostras com valores de ${ }^{13} \mathrm{C}_{\mathrm{CID}}$ entre $-8,0 \%$ e $-1,7 \%$ indicam zonas de dominância do intemperismo de carbonatos por ácido sulfúrico. Uma amostra do aqǘfero metassedimentar muito enriquecida em sulfatos, carbonatos, e em ${ }^{13} \mathrm{C}$, mostra que em alguns pontos a oxidação da pirita pode ser uma importante fonte para 0 intemperismo químico da rocha por ácido sulfúrico.
\end{abstract}

ABSTRACT. The salinization process of waters from Salitre basin were analyzed with the use of chemical and isotopic data from surface and ground water samples to evaluate the role of climatic and geologic factors in the salinity of waters of that basin. The more important aquifers of the Salitre basin are located in the metasedimentary rocks from the Chapada Diamantina Group and in the carbonates rocks from the Una Group and Caatinga Formation. Chemical data show a clear distinction between the two types of aquifers, with low concentration of dissolved salts in water from metasedimentary rocks and high concentration in water from carbonate rocks. The isotopic composition of hydrogen $(\delta \mathrm{D})$ and oxygen $\left(\delta^{18} 0\right)$ from ground and surface waters varied in a range of $33 \%$ and $4 \%$ (VSMOW) respectively. For waters from carbonate aquifer, $\delta$ D values from $-43 \%$ to $-10 \%$, and $\delta^{18} 0$ values from $-5,9 \%$ to $-3,3 \%$, with high concentration of dissolved salts, were identified the relative participation of three process of salinization. Samples with more negative isotopic values indicates dominance of transpiration and/or dissolution in the evaporitics rocks, while samples with less negative isotopic values indicate evaporation as predominant. Samples from metasedimentary aquifer, with $\delta$ D values from $-36 \%$ to $-20 \%$ and $\delta^{18} 0$ values from $-5,4 \%$ to $-3,5 \%$ indicate waters evaporated in a small degree and with low concentration of dissolved salts, except for one anomalous sample with a very high concentration of dissolved salts. Generally, waters from the surface reservoirs of Ourolandia, Tamburil and Caatinga do Moura show a high enrichment in heavy isotopes of hydrogen and oxygen due to evaporation. Wells sampled in the neighborhood of these reservoirs showed distinct isotopic values indicating no connection with these reservoirs. The isotopic composition of the dissolved inorganic carbon $\left(\delta^{13} C_{D I C}\right)$ of groundwater samples in the basin ranged from $-16,5 \%$ to $-1,7 \%$ (PDB), with samples from carbonate aquifers enriched in dissolved carbonates due to the interaction rock-water. The $\delta^{13} \mathrm{C}_{\text {DIC }}$ values from the samples made possible to identify the relative participation from two processes of salinization: weathering by carbonic acid and weathering by sulfuric acid. Samples group from carbonate aquifer with d13CDIC values from $-16,5 \%$ to $-8,0 \%$ indicates carbonates weathering by carbonic acid as dominant and samples with $\delta^{13} \mathrm{C}_{\mathrm{DIC}}$ values from $-8,0 \%$ to $-1,7 \%$ indicates carbonates weathering by sulfuric acid as dominant. One sample of the metasedimentary aquifer very rich in sulfates, carbonates and ${ }^{13} \mathrm{C}$, is an example of points where the pyrite oxidation can be an important source for chemical weathering in the rocks by sulfuric acid. 